\title{
Artikel
}

\section{Vervanging van de executeur door de kantonrechter}

\author{
Mr. L.A.G.M. van der Geld*
}

\section{Inleiding}

Een testateur kan bij de benoeming van een executeur in zijn uiterste wilsbeschikking bepalen dat als deze ontbreekt, de kantonrechter een vervanger kan benoemen. In artikel 4:142 lid 1 van het Burgerlijk Wetboek (BW) staat daarover: 'hij kan ook beschikken dat wanneer een benoemde executeur komt te ontbreken, de kantonrechter bevoegd is op verzoek van een belanghebbende een vervanger te benoemen'.

De afgelopen tijd werd ik in de praktijk meerdere malen geconfronteerd met de tot executeur benoemde echtgenoot van erflater van wie de goederen na het overlijden van erflater onder bewind werden gesteld. Op grond van artikel 4:143 lid $2 \mathrm{BW}$ kan de echtgenoot in deze situatie geen executeur worden. In de betreffende testamenten was de vervangingsclausule van artikel 4:142 lid 1 BW opgenomen. Hiermee werd mijn interesse in de uitwerking van de vervangingsclausule in de praktijk aangewakkerd.

\section{2 'Komt te ontbreken'}

De bevoegdheid die de testateur aan de kantonrechter kan toekennen, geldt als de 'benoemde executeur komt te ontbreken'. Wat betekent 'komt te ontbreken'? Er kunnen namelijk verschillende redenen zijn waarom de benoemde executeur niet in functie is. Onder meer omdat hij is vooroverleden, hij is overleden nadat hij de functie op zich heeft genomen, hij de benoeming tot executeur niet aanvaardt (art. 4:143 BW), zijn goederen onder bewind staan (art. 4:143 lid 2 BW) of omdat hij wordt ontslagen (art. 4:149 lid 1 onder $\mathrm{fBW}$ ). In de parlementaire geschiedenis lezen we dat het gaat om gevallen waarin 'de benoemde executeur bij het overlijden van de erflater - b.v. door vooroverlijden - blijkt te ontbreken of tijdens de executele wegvalt door vooroverlijden of ontslag. ${ }^{1}$

Mede gezien de parlementaire geschiedenis lees ik de wettekst 'wanneer een benoemde executeur komt te ontbreken' zo dat het gaat om situaties die zich voordoen direct na het maken van het testament waarin de executeur werd benoemd. Bijvoorbeeld: de persoon die de erflater tot executeur wilde benoemen, leefde op het moment van het maken van het testament, maar overleed enige tijd later vóór de testateur. Of: op het moment dat de testateur zijn echtgenote tot executeur benoemde in zijn testament waren haar goederen nog niet onder bewind gesteld, maar direct na zijn overlijden is het bewind uitgesproken over haar goederen. Als de testateur in zijn testament aan de kantonrechter de bevoegdheid heeft toegekend een vervanger voor de ontbrekende executeur te benoemen, dan maakt het mijns 
inziens niet uit waarom de benoemde executeur 'is komen te ontbreken'. ${ }^{2}$

De testateur kan de kantonrechter, anders dan dit bij bewind het geval is (art. 4:157 lid $1 \mathrm{BW}$ ), niet een executeur laten benoemen als hij niet (eerst) zelf een persoon tot executeur heeft benoemd. De bevoegdheid aan de kantonrechter toegekend om een vervanger te benoemen, wordt dus door de testateur verleend. Een automatische bevoegdheid voor de kantonrechter om een vervanger te benoemen past volgens de minister minder goed bij de beperkte duur van de executele. ${ }^{3}$ Met andere woorden: de testateur kan de benoeming van de eerste executeur niet delegeren aan de kantonrechter, de vervanging van de executeur wel. ${ }^{4}$ Volgens de parlementaire geschiedenis opent de vervangingsclausule in het testament voor de testateur de mogelijkheid in substitutie te voorzien 'zonder hiervoor zelf een bepaalde persoon aan te wijzen'.

\section{3 'Belanghebbende'}

De kantonrechter is bevoegd op verzoek van een belanghebbende een vervanger te benoemen. Wie is die belanghebbende? Volgens de parlementaire geschiedenis zijn in elk geval de erfgenamen, maar ook de schuldeisers, de lastbevoordeelden en de echtgenoot die aanspraak kan maken op verzorgingsvruchtgebruik, te verstaan onder 'belanghebbenden' in de zin van artikel 4:142 lid $1 \mathrm{BW} .{ }^{5}$ Gesteld kan worden dat onder belanghebbende moet worden begrepen iedereen die een rechtstreeks belang heeft bij de vervulling van de taak van de executeur. ${ }^{6}$ Overigens blijkt ook uit de parlementaire geschiedenis dat de testateur zelf bij de vervangingsclausule kan bepalen wie de belanghebbe(n) is

2. Een bestuurder van een bv kan onder opschortende voorwaarde worden benoemd. Dit lijkt enigszins op de situatie van de benoemde executeur: op het moment van het vervullen van de voorwaarde (bij de executeur: het overlijden van de testateur) kan de bestuurder zijn vooroverleden. In art. 2:244 lid 4 BW staat dat in de statuten van een bv een voorziening moet worden getroffen in het geval van belet of ontstentenis van één of meer bestuurders. Met belet wordt verwezen naar situaties waarin de bestuurder zijn functie tijdelijk niet kan of mag uitoefenen, bijv. door schorsing, langdurige ziekte of gedwongen verblijf in het buitenland zonder adequate communicatiemogelijkheden met de vennootschap. Volgens Asser/Maeijer moet onder 'ontstentenis' worden verstaan de situatie dat een bestuurder ophoudt bestuurder te zijn door ontslag, het neerleggen van zijn functie of overlijden (Asser/Maeijer, Van Solinge \& Nieuwe Weme 2-I* 2009/437). De benoeming van een bestuurder onder opschortende voorwaarde kan in de praktijk voorkomen als men een voorziening wil treffen voor het overlijden van bijv. de directeur-enig aandeelhouder. Hier is echter in het rechtspersonenrecht meer flexibiliteit dan in het erfrecht: in de statuten kan worden opgenomen dat de ontstentenisbepaling ook geldt als de bestuurder die is benoemd onder opschortende voorwaarde komt te ontbreken.

4. B. Schols, Executele, Deventer: Kluwer 2007, p. 214 en ook onder meer Rb. Leeuwarden 10 oktober 2003, ECLI:NL:RBLEE:2003:AO3411 (hier eindigde de executele door het ontslag van de executeur en kon geen vervanger worden benoemd omdat het testament daarin niet voorzag) en Rb. Assen 26 juni 2008, ECLI:NL:RBASS:2008:BD6671.

5. Parl. Gesch. Boek 4, Vaststellingswet Erfrecht, p. 839.

6. Schols 2007, p. 214 (zijn) die bij de kantonrechter om de benoeming van een vervanger kan (kunnen) verzoeken. ${ }^{7}$

Er zijn dus verschillende personen die naar de kantonrechter kunnen stappen om een vervanger te laten benoemen. Zijn deze personen verplicht om de kantonrechter te verzoeken een vervanger te benoemen zodra zij kennis hebben van het komen te ontbreken van de executeur? Uit de wettekst blijkt dit niet direct. Er zijn meerdere denkrichtingen mogelijk. Als we naar de aard van de executele kijken, dan zou betoogd kunnen worden dat uit de vervangingsclausule kan worden afgeleid dat de testateur coûte que coûte wil dat er een executeur is die zijn taak aanvaardt en uitvoert. Volgens Schols komt de quasi-overeenkomst van de executele immers niet tot stand op het niveau van de erfgenamen, maar op het niveau van de erflater: de benoemde executeur is de vertrouwenspersoon van erflater als erfrechtelijk vertegenwoordiger. ${ }^{8}$ De erfgenamen hebben slechts beperkte invloed op de aanwezigheid van de executeur: zij kunnen de kantonrechter verzoeken de executeur om gewichtige redenen te ontslaan (art. 4:149 lid 2 BW) of gebruikmaken van de in artikel 4:150 lid 2 en $3 \mathrm{BW}$ toegekende bevoegdheid. Als we wat dichter bij de parlementaire geschiedenis blijven, dan biedt de vervangingsclausule de testateur de mogelijkheid om bij de executele substitutie te regelen zonder dat hij zelf een persoon daartoe hoeft aan te wijzen. Vanuit dit oogpunt zou kunnen worden betoogd dat het niet alleen gaat om een mogelijkheid voor de testateur, maar ook voor de erfgenamen/belanghebbenden: als een executeur bij het ontbreken van de eerst aangewezen executeur gewenst is, dan hebben zij de mogelijkheid om de kantonrechter te verzoeken een vervanger te benoemen. Een executeur kan bijvoorbeeld gewenst zijn in verband met de (voorgenomen) beneficiaire aanvaarding en vanwege artikel 4:202 lid 1 onder a BW.

\section{De vervangingsprocedure}

De belanghebbende richt een verzoek aan de kantonrechter van de laatste woonplaats van de erflater.

De verzoeker kan zelf een vervangende executeur aandragen. Uit de Handleiding erfrechtprocedures (hierna: Handleiding) blijkt dat dan een bereidverklaring van die persoon met het verzoek moet worden meegezonden. ${ }^{9}$ Met het verzoek moet sowieso worden meegezonden: het testament, een verklaring van erfrecht en recente adresgegevens van andere belanghebbenden. Als door de verzoeker geen vervanger wordt voorgesteld, dan zoekt de kantonrechter volgens de Handleiding in de kring van de erfgenamen of naar een notaris, niet zijnde

7. Parl. Gesch. Boek 4, Vaststellingswet Erfrecht, p. 839: 'Wanneer de erflater in zijn uiterste wilsbeschikking niet slechts een of meer nader omschreven belanghebbenden, doch in het algemeen "belanghebbenden" bevoegd heeft verklaard (...).'

8. Schols 2007, p. 197

9. Handleiding erfrechtprocedures kantonrechter, vastgesteld door het LOK, 2008. 
de boedelnotaris, of een accountant. ${ }^{10}$ De verzoeker, de erfgenamen, de langstlevende en eventueel de voorgestelde executeur worden opgeroepen voor een zitting, maar er kan volgens de Handleiding ook met een schriftelijke akkoordverklaring worden gewerkt. Tegen de beschikking waarmee de vervangend executeur door de kantonrechter is benoemd, kan door belanghebbenden hoger beroep worden ingesteld. ${ }^{11}$

De benoeming van een vervangende executeur is een niet-inschrijfbaar feit in het boedelregister. De inschrijfbare feiten in het boedelregister (art. 4:186 BW) zijn limitatief in de wet genoemd. De vervanging van een executeur door de kantonrechter is niet een van de genoemde inschrijfbare feiten en is daarmee niet kenbaar uit het boedelregister.

\section{Belang voor de praktijk}

De executeur heeft het privatieve beheer over de goederen van de nalatenschap (art. 4:144 BW). De erfgenamen kunnen niet zonder zijn medewerking over de goederen van de nalatenschap beschikken (art. 4:145 BW). Het is dus van groot belang te weten of er een executeur is die zijn benoeming heeft aanvaard of dat de executeur is komen te ontbreken. De clausule in het testament waarmee de kantonrechter de bevoegdheid kan worden verleend een vervangende executeur te benoemen, speelt daarin een significante rol. Wat betekent dit voor de boedelafwikkeling en de testamentenpraktijk?

\subsection{De boedelafwikkeling}

Als de notaris wordt verzocht een verklaring van erfrecht en/of executele af te geven, moet hij zich ervan vergewissen of 'al dan niet het beheer van de nalatenschap aan executeurs (...) is opgedragen' (art. 4:188 lid 1 onder d BW). De in het testament benoemde executeur wordt verzocht zijn functie te aanvaarden (art. 4:143 BW). Als de benoemde executeur zijn functie niet aanvaardt of vanwege een andere reden sprake is van een ontbrekende executeur, controleert de notaris of in het testament een vervangingsclausule is opgenomen. Als er geen vervangingsclausule is opgenomen, dan vermeldt de notaris in de verklaring van erfrecht/executele dat de executeur is komen te ontbreken en dat op grond van het testament niet bij de kantonrechter om de benoeming van een vervangende executeur kan worden verzocht. Als in het testament de vervangingsclausule wel is opgenomen, dan gaat de notaris eerst na of er reeds een benoemingsbeschikking is afgegeven door de kantonrechter. Alhoewel de benoeming van een vervangende executeur niet kenbaar is uit het boedelregister, zullen de erfgenamen weet hebben van een procedure, omdat zij volgens de Handleiding worden opgeroepen voor een zitting. Verklaren de erfgenamen dat zij niet zijn opge-

10. Hof Amsterdam 22 maart 2007, ECLI:NL:GHAMS:2007:BA2332.

11. Handleiding erfrechtprocedures kantonrechter, vastgesteld door het LOK, 2008 en Hof Arnhem-Leeuwarden 19 september 2013, ECLI:NL:GHARL:2013:6918. roepen, dan verdient het de voorkeur - voordat door de notaris de verklaring van erfrecht/executele kan worden afgegeven - (alsnog) een verzoek in te dienen bij de kantonrechter om een vervangende executeur te benoemen. Afgezien van de vraag of er een verplichting op de erfgenamen rust dit verzoek in te dienen (zie hiervoor par. 3) of dat zij een executeur wensen, is het ook van belang voor de houdbaarheidsduur van de verklaring van erfrecht: als er namelijk na het afgeven van de verklaring van erfrecht door de kantonrechter een vervangende executeur wordt benoemd, dan is de verklaring van erfrecht vanwege het privatieve beheer van de vervangende executeur en de beperkte beschikkingsbevoegdheid van de erfgenamen (art. 4:145 BW) niet meer bruikbaar. ${ }^{12}$ Overigens zal de vervangende executeur een notaris de opdracht geven om een (nieuwe) verklaring van erfrecht te maken. De notaris die de 'eerste' verklaring van erfrecht heeft gemaakt, kan worden opgespoord via het boedelregister vanwege de verplichting van artikel 4:186 lid 2 BW (het zich inschrijven in het boedelregister van de notaris die betrokken is bij de afwikkeling van de nalatenschap).

Ook bijvoorbeeld bij een levering van een tot de nalatenschap behorend registergoed volgt de notaris bij het ontbreken van de benoemde executeur de hiervoor geschetste route. Mocht echter de afwikkeling van de nalatenschap reeds vergevorderd en op de verkoop van het registergoed na zijn afgerond, dan is goed verdedigbaar dat de notaris de vervangingsroute niet volgt. Naar analogie van artikel 4:150 lid 2 onder a BW zou de notaris in een dergelijk geval de erfgenamen een verklaring kunnen laten afleggen dat alle schulden van de nalatenschap (mogelijk behoudens de hypothecaire schuld) zijn voldaan en dat de eventuele lasten zijn nagekomen. ${ }^{13}$ In zo'n situatie zal het immers niet zinvol zijn de kantonrechter alsnog te verzoeken een vervangende executeur te benoemen.

\subsection{De testamentenpraktijk}

Anno 2016 wordt in bijna elk testament een executeur benoemd. De notaris heeft de testateur in de ontwerpfase geconfronteerd met de vraag of er in het testament een voorziening moet worden opgenomen voor het geval de benoemde executeur komt te ontbreken. Naast de clausule waarmee de kantonrechter de bevoegdheid wordt verleend een vervanger te benoemen, staat de testateur ook ander instrumentarium ter beschikking om te voorkomen dat met het ontbreken van de executeur de door hem gewenste executele vervalt. Gedacht kan wor-

12. De vergelijking met de situatie dat er een executeur is benoemd die zijn benoeming nog niet heeft aanvaard, gaat bij de nog openstaande mogelijkheid vervanging te vragen bij de kantonrechter, niet helemaal op. Er is immers geen executeur in persoon aanwezig die zich moet uitspreken. Tot geblokkeerde bevoegdheden bij de erfgenamen zou ik dan ook niet willen concluderen als er een vervangingsclausule in het testament staat, maar daar geen gebruik van is gemaakt. Zie voor de nog niet aanvaard hebbende executeur Schols 2007, p. 197.

13. Zie over art. 4:150 lid 1 BW ook Schols 2007, p. 326. Schols vergelijkt de in dit artikel opgenomen bevoegdheid van de erfgenamen met de Freigabe uit het Duitse recht. Als de taak van de executeur ten einde is, dan is hiermee nog niet het beheer over de nalatenschap ten einde. 
den aan één of meer 'reserve-executeurs'. Deze executeurs worden benoemd onder de opschortende voorwaarde dat een andere executeur komt te ontbreken. Daarnaast kan aan de benoemde executeur de bevoegdheid tot subrogatie en/of assumptie worden toegekend: hiermee is de executeur bevoegd een ander in zijn plaats te stellen of één of meer andere executeurs aan zich toe te voegen (art. 4:142 lid 1 BW). Door aan de indeplaatsstelling de opschortende voorwaarde van 'komen te ontbreken' toe te voegen is de executele beter verzekerd dan een direct in werking tredende subrogatie. Door de assumptie wordt aan risicospreiding gedaan: als de executeurs afzonderlijk van elkaar bevoegd zijn, vervalt de executele niet door het ontbreken van een van hen. Dit geldt ook als de testateur meer executeurs tegelijkertijd heeft benoemd. Als de testateur ervoor kiest een notaris(kantoor) tot executeur te benoemen, dan is er minder afhankelijkheid van een bepaalde persoon die kan komen te ontbreken.

Uit het instrumentarium waarmee de testateur kan worden verzekerd van de executele, kiest de notaris zorgvuldig, wetende welke gevolgen de keuze kan hebben voor de afwikkeling. Wil de testateur elk risico tegen elke prijs vermijden? Dan wordt de notaris voor de keus gesteld hoe te handelen en kan dit een vlotte afgifte van een verklaring van erfrecht/executele in de weg staan. De notaris moet dan namelijk kort gezegd een keuze maken tussen het afgeven van enerzijds een verklaring van erfrecht/executele die later niet meer bruikbaar kan blijken te zijn als een belanghebbende naar de kantonrechter stapt en anderzijds een verklaring van erfrecht/ executele waarvoor eerst wel bij de kantonrechter een vervangende executeur is verzocht. Er is geen blokkering in de beheers- en beschikkingsbevoegdheid van de erfgenamen zolang er geen vervangende executeur is benoemd. Zodra de door de kantonrechter benoemde vervangende executeur zijn taak heeft aanvaard, is er een privatieve beheersbevoegdheid voor de executeur en kunnen de erfgenamen alleen samen met de executeur beschikken (art. 4:145 BW).

\section{Tot slot}

Als een executeur komt te ontbreken, vervalt daarmee niet altijd de executele. In het testament van erflater kan een vervangingsclausule zijn opgenomen. Hiermee is de kantonrechter bevoegd op verzoek van een belanghebbende een vervangende executeur te benoemen. De belanghebbende kan zelf een vervangende executeur aandragen.

Of een vervangingsclausule is opgenomen in een testament is van belang voor de afwikkelingspraktijk. Mogelijk moet de notaris vanwege deze clausule op zoek naar de vervangende executeur of moet de kantonrechter alsnog worden verzocht een vervanger te benoemen. Dit betekent voor de testamentenpraktijk dat bij het maken van het testament bewust moet worden gekozen voor een vervangingsclausule. Er zijn immers ook andere alternatieven voor de testateur waarmee de aanwezigheid van een executeur kan worden zeker gesteld. 